\title{
Mediator of RNA Polymerase II Transcription Subunit 26
}

National Cancer Institute

\section{Source}

National Cancer Institute. Mediator of RNA Polymerase II Transcription Subunit 26. NCI Thesaurus. Code C28690.

Mediator of RNA polymerase II transcription subunit 26 (600 aa, $\sim 65 \mathrm{kDa}$ ) is encoded by the human MED26 gene. This protein plays a role in the positive regulation of transcription. 